\title{
Improving Yield, Fruit Quality and Leaf Mineral Content of Hayany Date Palm By the Application of Olive Pomance and Mineral Fertilization
}

\author{
Hoda S. H. Aly ${ }^{1}$ and M. M. Sourour ${ }^{2}$
}

\begin{abstract}
The present investigation was carried out during 2010 and 2011 seasons on Hayany date palm cultivar grown at El-Arish, North Sinai Governorate, Egypt, and depended on rainfall for irrigation, to study the effect of using olive pomace alone (as organic fertilizer) or in combination with nitrogen, phosphorus and potassium fertilizers on yield, fruit quality and some minerals content in leaves. The results could be summarized as follows. Fertilizing with 25 Kg olive pomace combined with N or NP or NK per palm tended to increase $\mathbf{N}$ content in pinnae as compared with other treatments. $\mathrm{K}$ content affected with the fertilization treatments, NK , $25 \mathrm{Kg}$ olive pomace + NK and control treatments gave the highest of values leaf $K$ content in both seasons. Moreover, $\mathrm{P}, \mathrm{Mg}$ and $\mathrm{Na}$ content in pinnae were not significantly affected by different fertilization treatments including the control in both seasons. However $\mathrm{Fe}, \mathrm{Zn}$ and $\mathrm{Mn}$ percentages were increased by adding olive pomace either alone or combined with mineral nutrients compared to other treatments. Concerning Ca content, no consistent trend was found between different treatments including the control. Moreover, adding olive pomace combined with NP and NK increased total chlorophyll in pinnae. As for the fruit chemical characteristics, no significant differences in TSS content in fruits were detected between different treatments including the control except treatment $\mathbf{N}$ which gave the lowest value. Regarding fruit total sugars content the application of olive pomace alone or combined with the minerals increased fruit total sugars content, as compared to mineral fertilization. Fruit tannins were significantly higher when palms were fertilized with olive pomace alone as compared to other treatments. Adding olive pomace combined with minerals (N, NP and NK) significantly increased yield / palm than that of the control. Fertilizing with $25 \mathrm{Kg}$ olive pomace combined with NK significantly increased the average fruit and pulp weight, fruit length and diameter as compared with the control. No significant differences were found between different treatments in seed weight. According to the conditions of this experiment, it is recommended to fertilize Hayany date palm with $25 \mathrm{Kg}$ olive pomace combined with NK which gave a reasonable yield with high fruit quality.
\end{abstract}

Key words: Date palm, organic fertilizer, olive pomace, leaf mineral content.

\section{INTRODUCTION}

Date palm (Phoenix dactylifera L.) tolerates the hard environmental conditions compared to other fruit trees. However, it needs fertilization with nutrient elements as other fruit trees. Nevertheless, experiments on date palm fertilization require more attention. Huge reductions in soil minerals content must be compensated annually by good fertilization programs in order to maintain the high yield and good quality of dates. However, the continuous use of chemical fertilization leads to deterioration of soil characteristics and fertility as well as it might lead to the accumulation of heavy metals in plant tissues which contribute to fruit nutrition value and edible quality (Shimbo et al., 2001). The second source of nutrients is organic manure which is derived from animal or plant sources. It is an excellent source of organic matter and macro- and micro-minerals. In addition to providing nutrients for crop growth, manure has several beneficial effects on soil properties. Application of organic fertilizers was found to improve structural stability and lowered bulk density of the soil. It improved moisture retention, water infiltration rate and the hydraulic conductivity of soil (Tisdale and Nelson 1987) and (Young, 1997). However, organic manure may be beneficial to crop and soil on the long term (Tirol-Padre et al., 2007), Similarly, soil fertility can be managed using organic fertilizers, crop rotation and association along with composting and recycling of the organic matter (Kenny and Hassan, 2006).

The primary use of ammonium sulfate was as a fertilizer for alkaline soils. In the soil the ammonium ion is released and forms a small amount of acid, lowering the $\mathrm{pH}$ balance of the soil, while contributing essential nitrogen for plant growth. The main disadvantage to the use of ammonium sulfate is its low nitrogen content relative to ammonium nitrate, (Karl-Heinz, 2012)

El-Arish is the capital and largest city of the Egyptian governorate of North Sinai, lying on the Mediterranean coast of the Sinai peninsula, 344 kilometers northeast of Cairo. The purpose here in nutrient management is to keep mineral nutrient levels in the tree with in the

\footnotetext{
${ }^{1}$ Hort. Res. Institute, Agric. Res. Center, Egypt.

${ }^{2}$ Fac. of Environmental Agric. Sci., El Arish,

Suez Canal Univ., Egypt.

E-mail: hoda_saad23@yahoo.com

Received October 7, 2012, Accepted December 13, 2012.
} 
desired range to have the growth and development effects and fruiting of trees as desired by the grower.

The present investigation was carried out to study the effect of using olive pomace alone (as organic fertilizer) or in combination with nitrogen, phosphorus and potassium fertilizers on yield, fruit quality and mineral content in leaves of Hayany date palm cultivar.

\section{MATERIALS AND METHODS}

The present investigation was conducted during 2010 and 2011 seasons on mature palm trees (20 yearsold) of Hayany date palm cultivars grown at El-Arish, North Sinai, Egypt. Selected palms in full production stage were chosen and subjected to the normal cultural practices, and depended on rainfall for irrigation. The average of rainfall rate was tabulated in Table (1) according to Willy Weather El Arish, QLD 4855.

Chemical analysis of olive pomace in both seasons was analyzed before used and presented in (Table 2).

Eight fertilization treatments were applied as shown in Table (3) each treatment was replicated four times with two palms for each replicate in a randomized complete block design (Snedecor and Cochran, 1990).

$\mathrm{N}$-as ammonium sulphate $(20.6 \% \mathrm{~N})$ was added at rate of $2 \mathrm{~kg} / \mathrm{palm}$ but with olive pomace $1 \mathrm{~kg}$ only. P-as calcium super phosphate $\left(15.5 \% \quad \mathrm{P}_{2} \mathrm{O}_{5}\right)$ was added at rate of $1.5 \mathrm{~kg} / \mathrm{palm}$. Potassium as potassium sulphate $\left(48 \% \mathrm{~K}_{2} \mathrm{O}\right)$ was added at rate of $1 \mathrm{~kg} / \mathrm{palm}$.

All fertilization treatments were applied once yearly at late of January in two holes with $75 \mathrm{~cm}$ diameter and $75 \mathrm{~cm}$ depth at a distance of $100 \mathrm{~cm}$ from the palm trunk on two sides in the first season and on the opposite sides in the second season.

The effect of different fertilization treatments on leaf mineral content, yield and fruit quality was determined as follows:

\section{Leaf mineral contents:}

Twenty pinnae (as a sample) from each experimental palm were collected at mid November in both seasons from the medium part of the five consecutive leaves which less were than one year old and located just over the fruiting zone as described by Rizk (1987).

1.1. Total nitrogen and phosphorus were determined calorimetrically according to Evenhuis (1976) and Murphy and Riley (1962), respectively.

1.2. Potassium was determined by Pertracourt PEP1 Flame Photometer (On dry weight basis) according to Brown and Lilleland (1946).

1.3. Calcium, magnesium,manganese, zinc and iron contents were determined using Perkin -Elmer Atomic Absorption Spectro-photometer Model 305 B.

Table 1. Average of rainfall rate $(\mathrm{mm})$ for 2010 and 2011 seasons

\begin{tabular}{ccccc}
\hline \multirow{2}{*}{ Month } & \multicolumn{2}{c}{$\mathbf{2 0 1 0}$} & \multicolumn{2}{c}{$\mathbf{2 0 1 1}$} \\
\cline { 2 - 5 } & Daily Average & Total amount & Daily Average & Total amount \\
\hline Jan & 22.8 & 681.0 & 17.1 & 529 \\
Feb & 13.0 & 365.2 & 35.0 & 980 \\
Mar & 19.5 & 605.0 & 34.0 & 1054.6 \\
Apr & 23.5 & 708.2 & 15.4 & 462.4 \\
May & 5.5 & 169.2 & 2.8 & 87.8 \\
June & 3.1 & 93.6 & 4.9 & 147.8 \\
July & 5.8 & 181.0 & 1.7 & 54.0 \\
Aug & 6.0 & 185.0 & 2.3 & 70.8 \\
Sept & 4.8 & 143.6 & 3.9 & 115.6 \\
Oct & 16.3 & 506.0 & 10.0 & 309.6 \\
Nov & 13.3 & 398.2 & 7.2 & 214.8 \\
Dec & 18.9 & 586.6 & 10.0 & 309.4 \\
\hline Average & 12.70 & 334.8 & $12 . .0$ & 361.3 \\
\hline
\end{tabular}

Table 2. Chemical analysis of olive pomace used in fertilizing 2010 and 2011 seasons

\begin{tabular}{|c|c|c|c|c|c|c|c|c|c|c|}
\hline $\begin{array}{c}\text { Moisture } \\
\%\end{array}$ & $\begin{array}{c}\text { Ash } \\
\%\end{array}$ & $\begin{array}{l}\text { Organic } \\
\text { matter \% }\end{array}$ & $\mathbf{N} \%$ & P\% & K \% & Сa \% & $\mathrm{Na} \%$ & $\begin{array}{c}\text { Fe } \\
\text { ppm }\end{array}$ & $\begin{array}{l}\text { Mn } \\
\text { ppm }\end{array}$ & $\begin{array}{c}\mathrm{Cu} \\
\text { ppm }\end{array}$ \\
\hline \multicolumn{11}{|c|}{2010} \\
\hline 23.45 & 5.3 & 41.21 & 3.12 & 0.09 & 0.45 & 0.47 & 0.35 & 1184 & 107 & 9 \\
\hline \multicolumn{11}{|c|}{2011} \\
\hline 24.98 & 5.1 & 40.74 & 3.07 & 0.09 & 0.47 & 0.47 & 0.36 & 1413 & 110 & 11 \\
\hline
\end{tabular}


Table 3. The layout of fertilization treatments during 2010 and 2011 seasons

\begin{tabular}{|c|c|c|c|}
\hline \multirow[b]{2}{*}{ Treatments } & \multicolumn{3}{|c|}{ Dosage/palm/year } \\
\hline & $\mathbf{N}(\mathrm{gm}) / \mathrm{palm}$ & $\mathrm{P}_{2} \mathrm{O}_{5}(\mathrm{gm}) / \mathrm{palm}$ & $\mathrm{K}_{2} \mathrm{O}(\mathrm{gm}) / \mathrm{palm}$ \\
\hline \multicolumn{4}{|c|}{2010} \\
\hline NPK (control) & 412 & 232.5 & 480 \\
\hline $\mathrm{N}$ & 412 & 0 & 0 \\
\hline NP & 412 & 232.5 & 0 \\
\hline NK & 412 & 0 & 480 \\
\hline $25 \mathrm{Kg}$ olive pomace & 780 & 22.5 & 112.5 \\
\hline $25 \mathrm{Kg}$ olive pomace $+\mathrm{N}$ & 986 & 22.5 & 112.5 \\
\hline $25 \mathrm{Kg}$ olive pomace $+\mathrm{NP}$ & 986 & 255 & 112.5 \\
\hline $25 \mathrm{Kg}$ olive pomace $+\mathrm{NK}$ & 986 & 22.5 & 592.5 \\
\hline \multicolumn{4}{|l|}{ - } \\
\hline NPK (control) & 412 & 232.5 & 480 \\
\hline $\mathrm{N}$ & 412 & 0 & 0 \\
\hline NP & 412 & 232.5 & 0 \\
\hline NK & 412 & 0 & 480 \\
\hline $25 \mathrm{Kg}$ olive pomace & 767.5 & 22.5 & 117.5 \\
\hline $25 \mathrm{Kg}$ olive pomace $+\mathrm{N}$ & 973.5 & 22.5 & 117.5 \\
\hline $25 \mathrm{Kg}$ olive pomace $+\mathrm{NP}$ & 973.5 & 457.5 & 117.5 \\
\hline $25 \mathrm{Kg}$ olive pomace $+\mathrm{NK}$ & 973.5 & 225 & 597.5 \\
\hline $\begin{array}{l}\text { 2. Total chlorophyll: } \\
\text { Total chlorophyll was } \\
\text { Minlota chlorophyll meter S } \\
\text { (A.O.A.C. 1995). } \\
\text { 3. Yield: }\end{array}$ & $\begin{array}{l}\text { pinnae by } \\
\text { according to }\end{array}$ & \multicolumn{2}{|c|}{$\begin{array}{l}\text { percentage of total soluble solids (TSS \%) was } \\
\text { determined in fruit juice by hand referactometer. While } \\
\text { chemical properties as total sugars and soluble tannins } \\
\text { were determined (\% on fresh weight basis) according to } \\
\text { Dubios et al. (1956) and Swain and Hillis (1959), } \\
\text { respectively. }\end{array}$} \\
\hline $\begin{array}{l}\text { The yield per palm in } \mathrm{Kg} \\
\text { October at the peak of fruitfu } \\
\text { 4. Fruit quality: } \\
\text { The fruit fresh weight }\end{array}$ & at the end of & \multicolumn{2}{|c|}{$\begin{array}{l}\text { Soil samples were taken at } 0-30 \mathrm{~cm}, 30-60 \mathrm{~cm} \text { and } \\
60-90 \mathrm{~cm} \text { from soil surface orchard for chemical analysis } \\
\text { and mechanical analysis of experiments and the data are } \\
\text { shown in (Table 4). }\end{array}$} \\
\hline
\end{tabular}
determined through collected sample of 20 fruits. Fruit quality was determined at harvest date, fruit weight, fruit length and diameter as physical properties. The

\section{Table 4. Soil analysis of the experimental orchard}

\begin{tabular}{|c|c|c|c|c|c|c|c|c|}
\hline \multirow{2}{*}{$\begin{array}{l}\text { Parameters } \\
\text { Soil Depth }\end{array}$} & \multicolumn{8}{|c|}{ (1) Chemical analysis } \\
\hline & \multicolumn{2}{|c|}{ pH } & \multicolumn{2}{|c|}{ E.C. $\left(\mathrm{dS} \mathrm{m}^{-1}\right)$} & \multicolumn{2}{|c|}{ Organic matter (\%) } & \multicolumn{2}{|c|}{ S.P. $(\%)$} \\
\hline $0-30 \mathrm{Cm}$ & \multicolumn{2}{|c|}{7.87} & \multicolumn{2}{|c|}{1.4} & \multicolumn{2}{|c|}{0.12} & \multicolumn{2}{|c|}{10} \\
\hline $30-60 \mathrm{Cm}$ & \multicolumn{2}{|c|}{7.91} & \multicolumn{2}{|c|}{0.9} & \multicolumn{2}{|c|}{0.12} & \multicolumn{2}{|r|}{10} \\
\hline \multirow[t]{3}{*}{$60-90 \mathrm{Cm}$} & & & & & & .11 & & 10 \\
\hline & \multicolumn{8}{|c|}{ Soluble ions soil paste extract (meq/L) } \\
\hline & $\begin{array}{c}\mathrm{Ca}^{++} \\
\mathrm{meq} / \mathrm{L}\end{array}$ & $\begin{array}{c}\mathrm{Mg}^{++} \\
\mathrm{meq} / \mathrm{L}\end{array}$ & $\begin{array}{c}\mathrm{Na}^{+} \\
\mathrm{meq} / \mathrm{L}\end{array}$ & $\begin{array}{c}\mathrm{K}^{+} \\
\mathrm{meq} / \mathrm{L}\end{array}$ & $\begin{array}{c}\mathrm{Co}_{3}^{-} \\
\mathrm{meq} / \mathrm{L}\end{array}$ & $\begin{array}{l}\mathrm{HCO}_{3}{ }^{-} \\
\mathrm{meq} / \mathrm{L}\end{array}$ & $\begin{array}{c}\mathrm{Cl}^{-} \\
\mathrm{meq} / \mathrm{L}\end{array}$ & $\begin{array}{l}\mathrm{HSO}_{4}{ }^{-} \\
\mathrm{meq} / \mathrm{L}\end{array}$ \\
\hline $0-30 \mathrm{Cm}$ & 2.79 & 1.9 & 7.10 & 1.3 & 0.27 & 4.3 & 5.47 & 3.05 \\
\hline $30-60 \mathrm{Cm}$ & 2.50 & 1.8 & 5.96 & 1.2 & 0.26 & 4.5 & 5.20 & 2.50 \\
\hline \multirow[t]{3}{*}{$60-90 \mathrm{Cm}$} & 2.62 & 1.9 & 7.90 & 1.5 & 0.27 & 4.1 & 5.90 & 3.65 \\
\hline & \multicolumn{8}{|c|}{ (2) Mechanical analysis } \\
\hline & \multicolumn{2}{|c|}{ Clay \% } & Silt \% & \multicolumn{2}{|c|}{ Fine Sand \% } & rse sand \% & \multicolumn{2}{|c|}{ Texture grade } \\
\hline Soil sample & \multicolumn{2}{|c|}{3} & 2 & \multicolumn{2}{|c|}{74.8} & 20.2 & \multicolumn{2}{|c|}{ Sandy } \\
\hline
\end{tabular}




\section{RESULTS AND DISCUSSION}

1. Effect of olive pomace and mineral fertilization treatments on pinnae minerals content of Hayany date palms:

As for the effect of different fertilization treatments on pinnae minerals content, the data in Table (5) showed that nitrogen content was affected with different fertilization treatments in both experimental seasons. Treatments, $25 \mathrm{Kg}$ olive pomace combined with $\mathrm{N}$ or $\mathrm{NP}$ or NK per palm significantly increase $\mathrm{N}$ content in pinnae as comparing with other treatments. This was true in both seasons.

Concerning phosphorus content in pinnae, no significant differences were found between different treatments including the control in both seasons except treatment $\mathrm{N}$ alone in the second season which gave the lowest value.

Regarding to $\mathrm{K}$ content, the results of both seasons Table (5) revealed that leaf $\mathrm{K}$ content was affected with the fertilization treatments, $\mathrm{NK}, 25 \mathrm{Kg}$ olive pomace combined with $\mathrm{NK}$ and control treatments gave the highest value comparing with $\mathrm{N}$ and NP treatments which gave the lowest values.
Generally no significant differences were found between different treatments in $\mathrm{Mg}$ and $\mathrm{Na}$ content, in pinnae including the control in both seasons, however $\mathrm{Fe}, \mathrm{Zn}$ and $\mathrm{Mn}$ percentage were increased by adding olive pomace either alone or combined with mineral nutrients compared to remaining other treatments.

Concerning $\mathrm{Ca}$ content, the obtained data show that there is no consistent trend in calcium content between different treatments including the control in both seasons. Organic manures enhanced soil properties and soil fertility (Mathew and Karikari, 1995) and (Kaurch et al., 2005) and might lead to the increase of available nutrients and their uptake (Kanal and Kuldkepp, 1993). The addition of organic manure might have provided supplemental exchangeable actions such as potassium, calcium, magnesium and ammonium as well as increasing the available phosphorous (Magdoff, 1998 and Ofosu-Anim et al., 2006). In this respect, the overall increase in leaf mineral contents, as a result of applying organic manure or organic fertilization in combinations with mineral fertilizer, in the present study might be explained in the light of results of previous studies.

Table 5. Effect of fertilization treatments on leaf minerals content (on dry weight basis) for Hayany date palm cultivar during 2010 and 2011 season

\begin{tabular}{|c|c|c|c|c|c|c|c|c|c|}
\hline \multirow[t]{3}{*}{ Treatments } & $\mathbf{N}$ & $\mathbf{P}$ & $\mathbf{K}$ & $\mathrm{Ca}$ & Mg & $\mathrm{Na}$ & $\mathbf{F e}$ & $\mathbf{Z n}$ & Mn \\
\hline & \multicolumn{6}{|c|}{$\%$} & \multicolumn{3}{|c|}{ ppm } \\
\hline & \multicolumn{9}{|c|}{2010} \\
\hline NPK (control) & $1.61 \mathrm{c}$ & $0.154 \mathrm{a}$ & $0.94 \mathrm{ab}$ & $1.13 b c$ & $0.20 \mathrm{ab}$ & $0.085 \mathrm{a}$ & $144.0 \mathrm{~b}$ & $55.43 \mathrm{c}$ & $58.70 \mathrm{~b}$ \\
\hline $\mathrm{N}$ & $1.62 \mathrm{c}$ & $0.152 \mathrm{a}$ & $0.70 \mathrm{c}$ & $1.13 \mathrm{bc}$ & $0.20 \mathrm{ab}$ & $0.083 \mathrm{a}$ & $144.7 b$ & $55.40 \mathrm{c}$ & $60.15 b$ \\
\hline NP & $1.60 \mathrm{c}$ & $0.154 \mathrm{a}$ & $0.71 \mathrm{c}$ & $1.08 \mathrm{~cd} 1$. & $0.20 \mathrm{ab}$ & $0.083 \mathrm{a}$ & $146.7 b$ & $5350 \mathrm{c}$ & $65.40 \mathrm{~b}$ \\
\hline NK & $1.62 \mathrm{c}$ & $0.157 \mathrm{a}$ & $0.93 \mathrm{ab}$ & $05 \mathrm{~d}$ & $0.19 b$ & $0.085 \mathrm{a}$ & $148.2 b$ & $66.50 \mathrm{~b}$ & $60.47 \mathrm{~b}$ \\
\hline $25 \mathrm{Kg}$ olive pomace & $1.69 \mathrm{~b}$ & $0.156 \mathrm{a}$ & $0.90 \mathrm{~b}$ & $1.19 \mathrm{ab}$ & $0.21 \mathrm{a}$ & $0.088 \mathrm{a}$ & $167.8 \mathrm{a}$ & $71.48 \mathrm{a}$ & $82.50 \mathrm{a}$ \\
\hline $25 \mathrm{Kg}$ olive pomace $+\mathrm{N}$ & $1.75 \mathrm{a}$ & $0.154 \mathrm{a}$ & $0.94 \mathrm{a}$ & $1.20 \mathrm{a}$ & $0.21 \mathrm{a}$ & $0.085 \mathrm{a}$ & $173.8 \mathrm{a}$ & $71.60 \mathrm{a}$ & $84.40 \mathrm{a}$ \\
\hline $25 \mathrm{Kg}$ olive pomace $+\mathrm{NP}$ & $1.74 \mathrm{a}$ & $0.160 \mathrm{a}$ & $0.95 \mathrm{a}$ & $1.15 \mathrm{abc}$ & $0.21 \mathrm{a}$ & $0.088 \mathrm{a}$ & $171.6 \mathrm{a}$ & $71.82 \mathrm{a}$ & $84.50 \mathrm{a}$ \\
\hline \multirow[t]{2}{*}{$25 \mathrm{Kg}$ olive pomace $+\mathrm{NK}$} & $1.72 \mathrm{a}$ & $0.157 \mathrm{a}$ & $0.97 \mathrm{a}$ & $1.12 \mathrm{bc}$ & $0.21 \mathrm{a}$ & $0.088 \mathrm{a}$ & $174.3 \mathrm{a}$ & $72.12 \mathrm{a}$ & $83.80 \mathrm{a}$ \\
\hline & \multicolumn{9}{|c|}{2011} \\
\hline NPK (control) & $1.86 \mathrm{~b}$ & $0.156 \mathrm{ab}$ & $0.66 \mathrm{ab}$ & $1.14 \mathrm{v}$ & $0.20 \mathrm{a}$ & $0.088 \mathrm{a}$ & $147.2 \mathrm{c}$ & $65.75 b$ & $69.74 \mathrm{~cd}$ \\
\hline $\mathrm{N}$ & $1.84 \mathrm{~b}$ & $0.144 \mathrm{~b}$ & $0.55 \mathrm{~d}$ & $1.15 \mathrm{c}$ & $0.20 \mathrm{a}$ & $0.083 \mathrm{a}$ & $148.1 \mathrm{c}$ & $55.83 \mathrm{c}$ & $69.90 \mathrm{~cd}$ \\
\hline NP & $1.78 \mathrm{c}$ & $0.148 \mathrm{ab}$ & $0.54 \mathrm{~d}$ & $1.14 \mathrm{c}$ & $0.20 \mathrm{a}$ & $0.085 \mathrm{a}$ & $147.6 \mathrm{c}$ & $55.52 \mathrm{c}$ & $67.28 \mathrm{~d}$ \\
\hline NK & $1.77 \mathrm{c}$ & $0.1464 \mathrm{~b}$ & $0.65 \mathrm{ab}$ & $1.14 \mathrm{c}$ & $0.20 \mathrm{a}$ & $0.085 \mathrm{a}$ & $149.4 \mathrm{c}$ & $69.50 \mathrm{~b}$ & $65.87 \mathrm{~d}$ \\
\hline $25 \mathrm{Kg}$ olive pomace & $1.68 \mathrm{~d}$ & $0.156 \mathrm{ab}$ & $0.64 b c$ & $1.18 \mathrm{~b}$ & $0.21 \mathrm{a}$ & $0.085 \mathrm{a}$ & $166.9 \mathrm{~b}$ & $75.00 \mathrm{a}$ & $73.37 \mathrm{a}$ \\
\hline $25 \mathrm{Kg}$ olive pomace $+\mathrm{N}$ & $2.605 \mathrm{a}$ & $0.156 \mathrm{ab}$ & $0.64 \mathrm{bc}$ & $1.18 \mathrm{~b}$ & $0.21 \mathrm{a}$ & $0.088 \mathrm{a}$ & $169.2 \mathrm{ab}$ & $73.28 \mathrm{a}$ & 73.10ab \\
\hline $25 \mathrm{Kg}$ olive pomace $+\mathrm{NP}$ & $2.035 \mathrm{a}$ & $0.161 \mathrm{a}$ & $0.62 \mathrm{c}$ & $1.20 \mathrm{~b}$ & $0.21 \mathrm{a}$ & $0.085 \mathrm{a}$ & $172.7 \mathrm{a}$ & $76.71 \mathrm{a}$ & 73.08ab \\
\hline $25 \mathrm{Kg}$ olive pomace $+\mathrm{NK}$ & $2.010 \mathrm{a}$ & $0.153 \mathrm{ab}$ & $0.66 \mathrm{a}$ & $1.22 \mathrm{a}$ & $0.21 \mathrm{a}$ & $0.083 \mathrm{a}$ & $173.1 \mathrm{a}$ & $75.02 \mathrm{a}$ & $73.39 \mathrm{a}$ \\
\hline
\end{tabular}

Means separation in each column by Duncan's Multiple Range Test, 5\% level 


\section{Effect of olive pomace and minerals fertilization treatments on pinnae chlorophyll content of Hayany date palms:}

Concerning the total chlorophyll in pinnae the data in Table (6) indicated that olive pomace combined with $\mathrm{NP}$ and NK in the first season and combined with N, NP and $\mathrm{NK}$ in the second season gave the highest value and the differences were statistically significant among these treatments and most of the other treatments These different levels of chlorophyll concentration would seem to be correlated with the differences in nitrogen availability between the treatments. These results coincided with those obtained by Hoda, Aly et al., (2009) on Zaghlou and Samany date palm cultivars.

\section{Effect of olive pomace and minerals fertilization treatments on some fruit chemical properties of Hayany date palms:}

Results presented in Table (6) indicated that there are no significant differences in TSS content in fruits between different treatments including the control except $\mathrm{N}$ treatment which gave the lowest value in both seasons.

Regarding fruit total sugars content, the data revealed that application of olive pomace alone or combined with the minerals in the second season increased fruit total sugars content as compared to mineral fertilization except NPK treatment but in the first season olive pomace combined with NK resulted higher significant value as compared with NPK, N, NP and olive pomace $+\mathrm{N}$.

Fruit tannins were significantly higher when fertilized with olive pomace alone as compared to fertilization with all other treatments in both seasons. Similar findings were reported by those found by ElDeeb et al., (2000) and Hoda Aly, (2003) the latest found that the palm trees fertilized by town refuse plus urea had a significant higher percentage of total sugars as compared with that fertilized with town refuse alone. Sharawy (2005) stated that the combined application of mineral nitrogen and compost, was effective in improving fruit quality of lime trees in comparison to application of each source alone. The general increase in fruit quality characteristics by the application of organic fertilizer or organic matter plus minerals NPK might be due to the increase in the availability $\mathrm{N}, \mathrm{P}$ and $\mathrm{K}$ in the soil due to the application of organic fertilizers (Magdoff, 1998) these essential nutrients may have a direct impact on photosynthesis and accumulation of dry matter and total soluble solids.

\section{Effect of olive pomace and minerals fertilization treatments on yield and some fruit physical properties and yield of Hayany date palms:}

Data of both seasons presented in Table 7, showed that fruit yield $(\mathrm{kg} / \mathrm{palm})$ was significantly higher in all olive pomace combined with minerals (N, NP and NK) treatments and the differences were statistically significant among them and all remaining treatments except olive pomace alone in the first season. Increasing yield due to using of olive pomace compared with control or other inorganic fertilizer may be due to the effect of organic materials in improving soil properties (Abdel-Nasser, and Harhash 2000), increasing nutrients content also may be explained on the basis that the organic materials increased the soil water holding capacity which encourage the solubility and consequently the available nutrients (Zaid and Kriem, 1992; El-Kassas et al.1997, Nassar, 1998, Kastens et al., and Marzouk and Kassem 2010).

The results remaining the effect of different fertilizers treatments on the various physical fruit characteristics are presented in Table (7). Fruit weight and pulp weight were increased in both seasons by applying olive pomace in combination with NP or NK and the differences were statistically significant in compared with all mineral treatments. No significant differences in seed weight were found between different treatments in both seasons except treatment $25 \mathrm{Kg}$ olive pomace $+\mathrm{NK}$ and control which gave the lowest value in the first season.

In regard to fruit dimensions, data of Tables (7) revealed a nearly similar trend as discussed for fruit weight, olive pomace in combination with NK significantly increased both fruit length and diameter as compared with all mineral treatments. in both seasons.

These findings are in harmony with those found by Hussein et al. (1992), Sourour et al. (1998), El-Deeb et al., (2000), Khan et al., (2008) and Marzouk and Kassem (2010). The above results indicated an enhancement in fruit quality characteristics especially fruit weight with the application of organic fertilizer or its supplementation with mineral NPK compared to mineral fertilization alone. Similar findings were reported by Shahein et al. (2003) working on Samany date. Also, Sharawy (2005) stated that the combined application of nitrogen, through mineral and compost, was effective in improving fruit quality of lime trees in comparison to application of each source alone. The general increase in fruit quality characteristics by the application of organic manure or organic manure plus mineral NPK compared to mineral NPK and N might be 
due to the increase in the available $\mathrm{N}, \mathrm{P}$ and $\mathrm{K}$ in the soil due to the application of organic fertilizers.

Conclusively, the obtained results give basis to conclude that adding olive pomace as organic fertilizer or organic matter in combination with minerals NPK for "Hayany" date palm under El-Arish, North Sinai, conditions (Egypt) is considered one of the most important practices to obtain reasonable yield/ palm with high fruit quality. The most beneficial treatment in this concern is application of olive pomace in combination with NK, which gave a reasonable yield and high fruit quality and could be considered as a recommended treatment under the conditions of this experiment.

Table 6. Effect of fertilization treatments on some fruit chemical properties and pinnae total chlorophyll (on fresh weight basis) for Hayany date palm cultivar during 2010 and 2011 seasons

\begin{tabular}{|c|c|c|c|c|}
\hline \multirow[t]{2}{*}{ Treatment } & TSS \% & Total sugar \% & Soluble tannin \% & $\begin{array}{l}\text { Total chlorophyll } \\
\text { SPAD reading }\end{array}$ \\
\hline & \multicolumn{4}{|c|}{2010} \\
\hline NPK (control) & $33.53 \mathrm{abc}$ & $36.92 \mathrm{~cd}$ & $3.82 \mathrm{~b}$ & $66.25 b$ \\
\hline $\mathrm{N}$ & $32.85 \mathrm{c}$ & $36.59 \mathrm{~d}$ & $3.82 \mathrm{~b}$ & $63.75 \mathrm{c}$ \\
\hline NP & $33.97 a b c 3$ & $37.32 \mathrm{bc}$ & $3.93 b$ & $67.40 \mathrm{ab}$ \\
\hline NK & $3.30 \mathrm{abc}$ & $37.43 \mathrm{abc}$ & $3.72 b c$ & $66.28 \mathrm{~b}$ \\
\hline $25 \mathrm{Kg}$ olive pomace & $34.06 \mathrm{ab}$ & $37.96 \mathrm{ab}$ & $4.46 \mathrm{a}$ & $65.22 \mathrm{bc}$ \\
\hline $25 \mathrm{Kg}$ olive pomace $+\mathrm{N}$ & $34 . .05 \mathrm{ab}$ & $36.56 \mathrm{~d}$ & $3.48 \mathrm{c}$ & $66.25 b$ \\
\hline $25 \mathrm{Kg}$ olive pomace $+\mathrm{NP}$ & $34.30 \mathrm{a}$ & $37.37 \mathrm{abc}$ & $3.92 b$ & $68.41 \mathrm{a}$ \\
\hline \multirow[t]{2}{*}{$25 \mathrm{Kg}$ olive pomace $+\mathrm{NK}$} & $34.38 \mathrm{a}$ & $38.05 \mathrm{a}$ & $4.02 b$ & $67.52 \mathrm{a}$ \\
\hline & \multicolumn{4}{|c|}{2011} \\
\hline NPK (control) & $35.51 \mathrm{abc}$ & 24.31ab & $3.51 \mathrm{~cd}$ & $65.40 \mathrm{abc}$ \\
\hline $\mathrm{N}$ & $34.20 \mathrm{bc}$ & $22.58 \mathrm{~b}$ & $3.39 \mathrm{~d}$ & $64.10 \mathrm{c}$ \\
\hline NP & $36.75 \mathrm{ab}$ & $23.19 b$ & $4.12 \mathrm{~b}$ & 66.30abc \\
\hline NK & $35.48 \mathrm{abc}$ & $23.33 b$ & $3.46 \mathrm{~cd}$ & $65.87 \mathrm{~b}$ \\
\hline $25 \mathrm{Kg}$ olive pomace & $35.57 \mathrm{abc}$ & $26.42 \mathrm{a}$ & $4.64 \mathrm{a}$ & 67.82ab \\
\hline $25 \mathrm{Kg}$ olive pomace $+\mathrm{N}$ & $37.85 \mathrm{a}$ & $27.12 \mathrm{a}$ & $4.20 \mathrm{~b}$ & $68.13 \mathrm{a}$ \\
\hline $25 \mathrm{Kg}$ olive pomace $+\mathrm{NP}$ & $37.57 \mathrm{a}$ & $27.57 \mathrm{a}$ & $3.54 \mathrm{c}$ & $68.10 \mathrm{a}$ \\
\hline $25 \mathrm{Kg}$ olive pomace $+\mathrm{NK}$ & $36.82 \mathrm{ab}$ & $27.81 \mathrm{a}$ & $3.50 \mathrm{c}$ & $68.28 \mathrm{a}$ \\
\hline
\end{tabular}

Means separation in each column by Duncan's Multiple Range Test, 5\% level

Table7. Effect of different fertilization treatments on some fruit physical properties and yield for Hayany cultivar during 2010 and 2011 seasons

\begin{tabular}{|c|c|c|c|c|c|c|}
\hline Treatment & $\begin{array}{c}\text { Fruit } \\
\text { weight (gm) }\end{array}$ & $\begin{array}{l}\text { Pulp weight } \\
\text { (gm) }\end{array}$ & $\begin{array}{l}\text { Seed weight } \\
(\mathrm{gm})\end{array}$ & $\begin{array}{c}\text { Fruit length } \\
\text { (cm) }\end{array}$ & $\begin{array}{c}\text { Fruit diameter } \\
(\mathrm{cm})\end{array}$ & $\begin{array}{c}\text { Yield } \\
(\mathrm{kg} / \mathrm{palm})\end{array}$ \\
\hline & \multicolumn{6}{|c|}{2010} \\
\hline NPK (control) & $22.77 \mathrm{~d}$ & $20.49 \mathrm{~d}$ & $2.29 \mathrm{~b}$ & $5.52 \mathrm{~b}$ & $2.60 \mathrm{e}$ & $84.78 \mathrm{c}$ \\
\hline $\mathrm{N}$ & $21.95 \mathrm{e}$ & $19.28 \mathrm{e}$ & $2.68 \mathrm{a}$ & $5.27 \mathrm{c}$ & $2.72 b c$ & $100.6 \mathrm{~b}$ \\
\hline NP & $23.01 \mathrm{~d}$ & $20.45 d$ & $2.56 \mathrm{ab}$ & $5.62 \mathrm{ab}$ & $2.72 b c$ & $90.59 \mathrm{bc}$ \\
\hline NK & $21.86 \mathrm{e}$ & $19.37 \mathrm{e}$ & $2.50 \mathrm{ab}$ & $5.31 \mathrm{c}$ & $2.69 \mathrm{~cd}$ & $85.80 \mathrm{c}$ \\
\hline $25 \mathrm{Kg}$ olive pomace & $25.99 \mathrm{c}$ & $23.37 \mathrm{c}$ & $2.62 \mathrm{ab}$ & $5.36 \mathrm{c}$ & $2.67 \mathrm{~d}$ & $109.1 \mathrm{ab}$ \\
\hline $25 \mathrm{Kg}$ olive pomace $+\mathrm{N}$ & $27.35 \mathrm{~b}$ & $24.87 b$ & $2.47 \mathrm{ab}$ & $5.65 \mathrm{a}$ & $2.76 \mathrm{ab}$ & $112.4 \mathrm{a}$ \\
\hline $25 \mathrm{Kg}$ olive pomace $+\mathrm{NP}$ & $27.77 \mathrm{a}$ & $25.33 \mathrm{ab}$ & $2.44 \mathrm{ab}$ & $5.71 \mathrm{a}$ & $2.72 b c$ & $115.7 \mathrm{a}$ \\
\hline \multirow[t]{2}{*}{$25 \mathrm{Kg}$ olive pomace $+\mathrm{NK}$} & $27.95 \mathrm{a}$ & $25.65 \mathrm{a}$ & $2.30 \mathrm{~b}$ & $5.70 \mathrm{a}$ & $2.80 \mathrm{a}$ & $118.2 \mathrm{a}$ \\
\hline & & & & 2011 & & \\
\hline NPK (control) & $24.25 \mathrm{~cd}$ & $21.50 \mathrm{c}$ & $2.55 \mathrm{a}$ & $5.54 \mathrm{~cd}$ & $2.68 \mathrm{c}$ & $79.33 d$ \\
\hline $\mathrm{N}$ & $23.87 \mathrm{~d}$ & $21.39 \mathrm{c}$ & $2.48 \mathrm{a}$ & $5.49 \mathrm{~d}$ & $2.71 \mathrm{c}$ & $70.56 \mathrm{~cd}$ \\
\hline NP & $24.53 \mathrm{c}$ & $22.10 \mathrm{c}$ & $2.44 \mathrm{a}$ & $5.51 \mathrm{~cd}$ & $2.63 \mathrm{~d}$ & $82.12 c$ \\
\hline NK & $24.31 \mathrm{~cd}$ & $21.59 \mathrm{c}$ & $2.57 \mathrm{a}$ & $5.52 \mathrm{~cd}$ & $2.70 \mathrm{c}$ & $81.80 \mathrm{c}$ \\
\hline $25 \mathrm{Kg}$ olive pomace & $25.01 \mathrm{c}$ & $22.48 \mathrm{ab}$ & $2.53 \mathrm{a}$ & $5.59 \mathrm{bc}$ & $2.68 \mathrm{c}$ & $108.00 \mathrm{bc}$ \\
\hline $25 \mathrm{Kg}$ olive pomace $+\mathrm{N}$ & $26.69 b$ & $24.15 b$ & $2.54 \mathrm{a}$ & $5.69 \mathrm{a}$ & $2.76 \mathrm{~b}$ & $125.50 \mathrm{a}$ \\
\hline $25 \mathrm{Kg}$ olive pomace $+\mathrm{NP}$ & $26.95 \mathrm{ab}$ & $24.44 \mathrm{ab}$ & $2.51 \mathrm{a}$ & $5.69 \mathrm{a}$ & $2.73 b c$ & $129.91 \mathrm{a}$ \\
\hline $25 \mathrm{Kg}$ olive pomace $+\mathrm{NK}$ & $27.39 \mathrm{a}$ & $24.90 \mathrm{a}$ & $2.49 \mathrm{a}$ & $5.70 \mathrm{a}$ & $2.82 \mathrm{a}$ & $133.43 \mathrm{a}$ \\
\hline
\end{tabular}

Means separation in each column by Duncan's Multiple Range Test, 5\% level 


\section{REFERENCES}

Abdel-Nasser, G. and M.M. Harhash (2000). Effect of organic farming in combination with elemental sulphur on soil physical and chemical characteristics, yield, fruit quality, leaf water contents and nutritional status of Flame seedless grapevines I. Soil physical and chemical characteristics. J. of Agric. Sci., Mansoura Univ. 25(4), 3541-3558.

A.O.A.C. (1995). Association of Official Agricultural Chemists, Official Methods of Analysis. (15th ed.)A.O.A.C., Washington, DC (1995).

Brown J.D. and O. Lilleland (1946). Rapid determination of potassium and sodium in plant material and soil extracts by flamephotometer. Proc. Amer. Soc. Hort. Sci. 48: 341 346.

Dubios, M.; K.A. Gilles; J.K. Hamitton; P.A. Robers and F. Smith (1956). Colorimetric method for determination of sugars and related substances. Anal. Chem. 28(3): 350356.

El-Deeb, M.D.; M.M. Sourour and K.A. Ismail (2000). Use of olive pomace and mineral fertilizers for "Hayany" date palms fertilization. Proceeding of the date palm International symposium, Windhoek, Namibia Pp. 103115.

El-Kassas, H.I.; A.F. Abou-Hadid and N.M.H. Eissa (1997). Effect of different organic manures on the yield and elemental composition of sweet pepper plants grown on sandy soil. Egypt. J. Appl. Sci. 12(3): 262-281.

Evenhuis, B. (1976). Nitrogen determination. Dept. Agric. Res. Royal Tropical Inst., Amsterdam.

FAO, Statistical Database; http://faostat.fao.org, accessed 2 March (2005).

Hoda, S.H. Aly (2003). Nutritional status, yield, fruit quality and fruit nitrate, nitrite and some heavy metals contents of Zaghloul and Samany date palm cultivars in relation to fertilizing with different organic and inorganic nitrogen sourcs. Ph.D. Thesis, Agric. Univ. Alex., Egypt.

Hoda, S.H.Aly; M.R. El-Shenawy and M. Badran (2009). Effect of Addition city garbage as a nitrogen source either alone or in combination with each nitrate or urea on Zaghloul and Samany date palm cultivars. Alex. Sci. Ex. J., 30(1): 86-95.

Hussein, M.A.; S.Z. El-Agamy; Kamelia, I.A. Amen and S. Galal (1992). Effect of certain fertilization and thinning applications on the yield and fruit quality of Zaghloul date palm. Assiut. J. Agric. Sci. 23(2): 349-360.

Kanal, A.; Kuldkepp, P. (1993). Direct and residual effect of different organic fertilizers on potato and cereals. J. Agron. Crop Sci., 171, pp. 185-195.

Karl-Heinz Z. (2012). Ammonium Compounds in Ullmann's Encylopedia of Industrial Chemistry, Wiley-VCH, Weinheim. doi:10.1002/14356007.a02_243.
Kastens, T.L., J.P. Schmdt and K.C. Dhuyvetter ( 2003). Yield models implied by traditional fertilizer recommendations and a framework for including nontraditional information. Soil Sci. Soc. Am. J. 67:353-364.

Kaurch, K.; Kapoor, K.; Gupta, A. (2005). Impact of organic manures with and without mineral fertilizers on soil chemical and biological properties under tropical conditions J. Plant Nutr. Soil Sci., 168, pp. 117-122

Kenny, L. and I.A. Hassan (2006). Converting date palm ceases to organic farming: possibilities and constraints. Abstract of the Third International Date Palm Conf. Feb. $19^{\text {th }}-21^{\text {th }}$, Abu Dhabi.

Khan, M. N.; A. Sarwar; M.F. Wahab; and R. Haleem (2008). Physico-chemical characterization of date varieties using multivariate analysis. J. Sci. Food Agric., 88: 1051-1059. doi: 10.1002/ jsfa.3187. M. Nasiruddin Khan ${ }^{1}$

Magdoff, F. (1998). Building Soils for Better Crops: Organic Matter Management Ohio Agronomy Guide, Bulletin, 672.

Marzouk, H.A. and H.A. Kassem (2011). Improving fruit quality, nutritional value and yield of Zaghloul dates by the application of organic and/or mineral fertilizers. Soil and Tillage Research, Vol 104: 221226.

Mathew, S.K. Karikari (1995). Horticulture Principles and Practices..Macmillan Education Ltd, London and Basingtroke pp. 80-84.

Murphy, J. and J. P. Riley (1962). A modified single solution method for the determination of phosphorus in natural waters. Anal. Chem. Acta 27: 31-36.

Nassar, I.N. (1998). Utilization of the municipal Garbage (MG). As a soil Amendment Alex. J. Agric. Res. 43(3): 317-332.

Ofosu-Anim, J.; Baly, E.T.; Frempong, M.E. (2006).Effects of organic manure on okra (Abelmoschus esculentus (L.) Moench) production. J. Appl. Hort., 8, pp. 155-158.

Rizk, S.A.Y. (1987). Studies on the effect of fertilization on date palm production. Ph.D. Thesis. Fac. Agric., Ain Shams Univ., Egypt.

Sharawy, A.M.A. (2005). Response of Balady lime trees to organic and biofertilization Minia J. Agric. Res. Dev., 25, pp. 1-18.

Shimbo, S.; Watanabe, T.; Zhang, Z.W.; Ikeda M (2001). Cadmium and lead contents in rice and other cereal products in Japan.

Snedecor, C.W. and W.G. Cochran (1990). Statistical methods $7^{\text {th }}$ ed. The Iowa State Univ. Press. Ames Iowa. USA. P. 593.

Sourour, M.M.; M.B. El-Sabrout and I.A. Mousa (1998). Effect of some sea weeds and mineral nitrogen fertilization treatments on growth, yield, fruit quality and nutritional status of "Samany" and "Hayany" date palms grown in North-Sinai. Egypt. J. Appl. Sci., 13(12):247-261. 
Swain, T. and W.E. Hillis (1959). The phenolic constituents of Prunus domestica. I. The quantitative analysis of phenolic constituents. J. Sci.Food Agric., 10: 63-68.

Tirol-Padre, A.; Ladha, J.K.; Regmi, A.P.; Bhandari, A.L.; Inubushi K. (2007). Organic amendments affect soil parameters in two long-term rice wheat experiments. Soil Sci. Soc. Am. J., 71, pp. 442-452.
Tisdale, S.L. and Nelson, W.L. (1987). Soil Fertility and Fertilizers. Macmillan Publishing Co. Inc., New York, USA, pp. 67-70.

Young (1997). Agroforestry for Soil Management. CAB International, Wallingford, Oxan, UK (1997) pp. 98-100

Zaid, M.S. and H.M. Kriem (1992). Effect of sugar cane wastes and sulphur on some soil properties and nutrients uptake by Zea maize plants in sandy soil. J. Agric. Sci. Mansoura Univ. 17(1):181-188.

\section{الملخص العربي}

\section{تحسين الخحصول وجودة الثمار بإضافة مخلفات عصر الزيتون والتسميد المعدلى للنخيل صنف الحيالن}

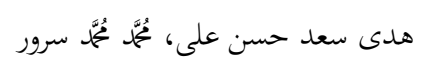

كذلك فإن مخلفات عصر الزيتون مختلطه بـ NP أوNK تزيد من محتوى

الكلوروفيل في الوريقات. أما بالنسبه للخصائص الكيماويه في الثمار

فقد أظهرت النتائج أنه لايوجد فروق معنويه بين المعامالات ماعدا معاملة النيتروجين منفردا التى أعطت أقل محتوى من المواد الصلبه الذائبه. أما بالنسبه للسكريات الكليه فقد أظهرت النتائج أن أضافة مخلفات عصر الزيتون أما منفرده أو مخلوطه بالتسميد المعدن أعطت زياده في محتوى الثمار من السكريات الكليه بالمقارنه بالتسميد المعدنى منفردا. وظهرت أعلى زياده معنويه للتانينات عند أضافة مخلفات عصر الزيتون منفردا بالمقارنه بباقى المعاملات. إضافة مخلفات عصرالزيتون مخلوطه بالعناصر المعدنيه مثل NK و N, NP أعطت زياده معنويه لمحصول النخله عن معامله الكنترول. التسميد بـ 25 كجم من مخلفات عصر الزيتون مخلوطه بـNK سببت زياده معنويه من متوسط وزن ولب وطول وقطر الثمره بالمقارنه بالكنترول. لايوجد فروق معنويه عند التسميد بالمعاملات المختلفه على وزن البذره طبقا لما سبق فقد أظهرت التوصيات لهذا البحث أن تسميد الحيانى بـ25 كجم من مخلفات الزيتون مخلوطا بـ NK أعطت أعلى تأثير على الخصول وأفضل صفات جودة للثمار.
أجريت التجربه خلال موسمى 2011/و 2012 على نخيل البلح

صنف الحيانى المزروع بالعريش,محافظة شمال سيناء, مصر تحت ظروف الرى بمياه الأمطار. وذلك لدراسة تأثير أستخدام مخلفات عصر الزيتون منفردا كمصدر عضوى أو خلوطا بالنيتروجين أو الفوسفور أوالبوتاسيوم أوالتسميد المعدنى منفردا على المحصول وجودة الثمار وبعض العناصر المعدنيه بالأوراق. وكانت النتائج كالتالى: التسميد بـ 25 كجم من مخلفات عصر الزيتون مخلوطه بالعناصر المعدنيه الأخرى N أو NR أو NK أعطت أعلى محتوى من النيتروجين بالوريقات بالمقارنه بباقى المعاملات الأخرى. أما محتوى البوتاسيوم فقد تأثر وأعطى أعلى محتوى مع أومخلفات عصر الزيتون خلوطاب NK والكنترول(المقارنه)وذلك فن كلا الموسمين بينما محتوى الفوسفور والمغنسيوم والصوديوم لم يتأثر معنويا بكل المعاملات بما فيها الكنترول في كلا الموسمين. وقد زاد محتوى الحديد والزنك والمنجنيز في الوريقات بإضافة مخلفات عصر الزيتون إما منفردا أوخلوطا بالأسمده المعدنيه بالمقارنه بباقى المعاملات. أما محتوى الكالسيوم فلم يظهر أى أبتاه واضح فن كلا الموسمين. 